\title{
The Validity of the Consumer Financing Agreement With the Standard Clause of the Fiduciary Guarantee
}

\author{
Djulaeka \\ Faculty of Law, University of \\ Trunojoyo Madura \\ E-mail: djulaeka@trunojoyo.ac.id
}

\begin{abstract}
Standard clauses are often an integral part of the Consumer Financing Agreement with Fiduciary Guarantees. The provisions of the standard clause are expressly regulated in Article 18 of Law Number 8 of 1999 concerning Consumer Protection. In Burgelijk Wetboek's perspective, the inclusion of a standard clause that is integrated into the agreement cannot be directly interpreted as having an agreement being canceled. This article analyzes the Court's decision regarding consumer disputes in the implementation of the Consumer Financing Agreement so that a legislative approach is needed with a knife analysis of the case approach. The statute approach is carried out by analyzing the validity of the Consumer Financing Agreement related to the contents of the standard clause, the validity of the principles in the contract as stipulated in the Wetboek Burgelijk and the meaning of the regulation of the cancellation of a standard clause in Law Number 8 of 1999 concerning Consumer Protection. Through the case approach it is found that there is no correlation between the standard clause and the cancellation of a consumer financing agreement.
\end{abstract}

Keywords: community participation, women, victims

\section{INTRODUCTION}

Consumer finance is part of the needs of the community as consumers in the procurement of an item that is considered as an alternative to the installment or periodic payment system by consumers. Along with the needs of the community in finding alternative sources of financing, an agency that is engaged in financing consumers through the Financing Company is required as referred to in the provisions of Presidential Regulation Number. 9 of 2009 concerning Financing Institutions. In consumer financing since the beginning of ownership of goods / objects of financing are with consumers.

Some of the reasons for the formation of a finance company, among others, First, the limited source of formal funds that previously only existed Perum Pegadaian but considered less flexible in meeting the needs of public funds. Second, the existence of savings and loan cooperatives that are difficult to develop due to problems of management, guidance, supervision that is not good so that it is less trusted by the community and in turn difficult to develop themselves. Third, banking institutions do not provide credit facilities that are consumptive and small in size and the existence of collateral principles making it difficult for middle and lower class people. Fourth, financing through loan sharks / loan sharks with high interest and even tends to be unnatural very dangerous for the community.[1]

In the context of the Civil Code, the engagement between consumers as those who need procurement of goods and financing institutions, of course, is framed by an agreement / contract that can be binding between the two parties to fulfill the achievements as agreed by both. The tendency that occurs in the community, that the agreements made by Financial Service Business Actors as Financing Institutions with Consumers as debtors are standard agreements (read: standard contracts) that have been prepared unilaterally by Financial Service Business Actors. Many problems arise in the community under the pretext that consumers do not understand the existence of the clause 'declaring authorization from Consumers to Financial Service Institutions, both directly and indirectly, to take all unilateral actions on goods that are pledged by Consumers' that are inherent in the standard contract consumer finance. A dispute arises that it is assumed that with the debtor having been breached, the application of the clause that has been embedded in the financing agreement has been signed by the parties.

In the implementation of the standard contract the consumer is only faced with 2 (two) choices, namely: (1). If the consumer needs the goods or services offered to him, a contract is agreed with the standard terms offered by the entrepreneur (take it); or (2). If the consumer does not agree with the terms offered, do not make a contract with the employer concerned (leave it).[1] So that the other mention of this contract is known as the take it or leave it contract and is also known as an adhesion contract. Some cases that are often considered detrimental to consumers and often must be resolved through a court related to the existence of a standard clause in this consumer financing agreement, raises the legal issue "Are the standard clauses in consumer financing agreements with fiduciary guarantees always considered null and void?"

The main legal issues for this articles can be examined with two legal perspectives is the first perspective examined from of Law Number 8 of 1999 concerning Consumer Protection and the Regulations stipulated in the Financial Services Authority ; the second perspective is examined from of Civil Law in General through a Burgelijk Wetboek (hereinafter referred to as BW) and Law Number 42 of 1999 concerning Fiduciary Guarantees. 


\section{METHODOLOGY}

\section{A. Type of Research}

The research in this study is normative legal research as a process of finding legal rules, legal principles, and legal doctrines in order to address the legal issues encountered in accordance with the characteristics of the prescription of legal sciences.[2]

\section{B. Problem Approaches and Legal Materials}

The approach used in this legal study is the statutory approach and the case approach. Statute approach (statute approach) that is done by examining all laws and regulations relating to the legal issues being handled. Whereas the case approach is carried out by examining cases relating to the issues faced which have become court decisions that have permanent powers.

The legal material needed in studying and reviewing this article is primary legal material and secondary legal material. Primary legal materials that are related are: (1) Burgelijk Wetboek (BW); (2) Law Number 8 of 1999 concerning Consumer Protection; (3) Law Number 42 of 1999 concerning Fiduciary Guarantees; (4) Presidential Regulation Number 9 of 2009 concerning Consumer Financing; (5) Regulation of the Minister of Finance of the Republic of Indonesia Number 84 / PMK.012 / 2006 concerning Financing Companies; Regulation of the Minister of Finance of the Republic of Indonesia Number 130 / PMK.010 / 2012 concerning Registration of Fiduciary Guarantees; (6) Financial Services Authority Regulation Number: 1 / POJK.07 / 2013 Concerning Consumer Protection in the Financial Services Sector: (7) Decision of the Pekalongan District Court Number: 42 / Pdt.G / 2011 / PN PKL; (8) Bengkayang District Court Decision Number: 02 / Pdt.G / BPSK / 2014 / PN.Bky; (9) Court Decision of the Constitutional Court No. 18 / PUU-XVII / 2019 related to the Execution of Fiduciary Guarantees.

Secondary Legal Materials in the form of all publications on law that are not official documents, including textbooks and legal journals, as well as other references that are relevant to the legal issues examined in this article.

\section{Analysis of Legal Materials}

Analysis of legal materials is carried out deductively by reviewing legal materials that have been systematically identified as a knife for analysis so that answers and recommendations related to legal issues will be found in this article.

\section{RESULT AND DISCUSSION}

\section{A. Legal Relations of The Parties In The Consumer Financing Contract}

In each agreement must comply with the provisions of Article $1320 \mathrm{BW}$ as a condition for the validity of an agreement, that "For the validity of the agreement, 4 (four) conditions are required, including: (1) agreeing on those who bound themselves; (2) the ability to make an engagement; (3) a certain thing; (4) a lawful cause. Causa or cause in the Law of Agreement is the content and purpose of an agreement, which causes the agreement. Causa is different from "motives", the motivating reason for something. The reason for this impetus is in a person's mind, so in the realm of the law does not mean as essence.[3] The four conditions must be fulfilled by the parties involved in the consumer financing agreement.

The BW regulation provides that if there are no subjective conditions (point 1 and point 2), the agreement made has made the agreement can be canceled. Conversely, if the requirements for points 3 and 4 are not fulfilled, the agreement can be said null and void by law. The existence of a standard clause contained in the consumer financing agreement when examined is part of the efforts of one party (business actor) to facilitate the making or implementation of the agreement itself, so that it has been prepared unilaterally by a business actor (read: financial institutions). Characteristics of a standard clause can be known through several things: (1). A clause in an agreement made unilaterally by a business actor, whose position is relatively stronger than consumers; (2). Consumers are not involved at all in determining the contents of the clause; (3). Made in writing and in bulk; and (4). Consumers are forced to accept the contents of the agreement because it is driven by needs.

In the BW perspective, the standard clause that is always contained in the consumer financing agreement, can be interpreted as part of fulfilling the 1st point requirements of the provisions of Article $1320 \mathrm{BW}$, because in the context of an 'agreement', the parties are faced with the position of showing the existence of 'equality in will' . The meaning of 'similarity in will' gives a signal that between 'will' and agreed statement 'both have agreed which really agrees or there is no 'defect in the will' element.

In the standard agreement that should be feared if there is an exoneration clause. Exoneration clause is a clause containing restrictive conditions, or even completely eliminate the responsibility that should be charged to the business actors.[4] However, in the context of consumer financing agreements, the parties (especially consumers) are faced with those who need it (read: weak) so that they always position themselves in an effort to accept whatever is offered by business actors. The realization that the consumer accepts the 'offer' or the will of the business actor is always interpreted when an agreement has been signed between the two, so that it has been assumed that both the business actor and the consumer have 'agreed', without paying deeper attention to the existence of a standard clause that might be detrimental to the consumer. So there is an assumption that the contract made and in it contains elements of a standard clause called the standard contract / agreement, as mentioned by Abdul Kadir Muhammad, the term standard 
agreement is translated from a term known in the Dutch language that is -standard contract. The word standard or standard means the benchmark used as a benchmark or guideline for every consumer who establishes legal relations with employers, which is standardized in a standard agreement is covering the model, formulation, and size.[5]

In accordance with the principle of 'pacta sunt servanda', the 'agreement' between the two parties has juridical consequences that the consumer financing agreement is legitimate and binding both as is the law (Article 1338 (2) BW). Both can not force a cancellation of the agreement without going through a judicial process, as observed in the provisions of Article $1266 \mathrm{BW}$ juncto Article $1267 \mathrm{BW}$

\section{B. Standard Clause In The Perspective Study of The Consumer Protection Act And Financial Services Authority Regulations}

Inclusion of standard clauses in every agreement made by business actors and consumers is always considered to be unbalanced or biased because consumers are always considered to be in a weak bargaining position, so often this agreement is called take it or leave it contract. This agreement in the context of consumer financing is known as a consumer financing agreement made between the financial institution as a business actor and the consumer as the party who needs the services provided by the financial institution. This agreement is commonly known as a consumer financing agreement. provide consumer finance (consumer finance) as stipulated in Presidential Regulation No. 9 of 2009 concerning Financing Institutions.

Law Number 8 of 1999 concerning Consumer Protection provides specific arrangements relating to standard clauses[6]In line with this regulation, Regulation of the Financial Services Authority Number: 1 / POJK.07 / 2013 Concerning Consumer Protection in the Financial Services Sector in Article 22 Paragraph 3 states that "Standard agreements as referred to in paragraph (2) used by Financial Service Business Actors are prohibited: (a) ...; (c), that: "declares authorization from the Consumer to Financial Services Business Actors, both directly and indirectly, to take all unilateral actions on goods pledged by the Consumer, unless such unilateral actions are carried out based on statutory regulations". Although the mention of a standard agreement in this provision, it gives the meaning that the prohibition in question constitutes 'inclusion of a standard clause'. So that this can provide guidelines for the parties in making financing contracts must pay attention to the interests of consumers. This prohibition puts the position of consumers on a par with business actors based on the principle of freedom of contract.

The thing that distinguishes in principle in the validity of these two regulations, is that Law Number 8 of 1999 concerning Consumer Protection considers 'null and void' if the business actor includes the standard clause, whereas in the Financial Services Authority Regulation Number: 1 / POJK.07 / 2013 Concerning Consumer Protection the Financial Services Sector is subject to administrative sanctions in the form of: (a). Written warning; (b). Fines are obligations to pay a certain amount of money; (c). Limitation of business activities; (d). Suspension of business; and e. Revocation of business activity permit.

\section{Fiduciary Guarantees In The Financing Agreement}

According to Law Number 42 of 1999 concerning Fiduciary Guarantee, it is stated that Fiduciary is the transfer of ownership rights of an object based on trust with provision that objects whose ownership rights are transferred remain in the possession of the owner of the objects, whereas...[7] From the formulation of the provisions of this article, then in the fiduciary guarantee there are elements including: the fiduciary parties, the fiduciary recipient and collateral objects. The existence of this fiduciary guarantee is an inseparable part related to the financing agreement as the main agreement.

The purpose of the fiduciary guarantee agreement in terms of legal protection for creditors is to grant privileges or rights precedence for him to repay his debts, debtors to him (schuld and haftung principles).[8] Consumer financing agreements are always followed by guarantees as a legal means for securing repayments of cash loans or loans given to consumers. The existence of this fiduciary guarantee will bring problems, if the fiduciary parties cannot fulfill its main obligations in accordance with an agreement that has been made jointly with the fiduciary recipient (financial institution).

Prior to payment in full, all ownership documents for goods are held by consumer finance companies as fiduciary guaratee. If the consumer defaults in the sense of being unable to pay (bad), then the consumer finance company based on the power to sell, sell goods to cover consumer debt that has not been paid. However, this does not mean that the business actor (fiduciary recipient) can execute the collateral material, as stipulated in Article 3 of the Minister of Finance Regulation No. 130 / PMK.010 / 2012, that finance companies are prohibited from withdrawing fiduciary objects in the form of motorized vehicles if the Fiduciary Registration Office has not issued a fiduciary guarantee certificate and submitted it to the finance company

\section{Analysis Of Court Decision Number 42 / Pdt.G / $2011 /$ Pn Pkl}

This decision is a decision containing the principle of 'good faith' where the parties must position themselves in a balanced, honest and transparent manner. The position of the case [9] illustrates the existence of parties between the Plaintiffs (Sri Wiyani) and PT. Adira Dinamika Multy Finance, Tbk, the Company is domiciled in Jakarta Cq., PT. Adira Dinamika Multy Finance, TBK (hereinafter referred to as PT Adira) Pekalongan Branch office. The claim of the Plaintiff is a violation of law by PT Adira because in the Joint Financing Agreement Number 0408.11.200122 violates the provisions of Article 18 of the Law No. 8 of 1999 with the inclusion of a standard clause stating 'All and every power granted by the Debtor and / or Guarantor to the Creditor based on the agreement is an inseparable part of this agreement, thus this power cannot be withdrawn ..., and for granting guarantees of payment of all obligations ... hereby the Debtor 'hands over to the Creditor his fiduciary rights', if the Debtor fails to carry out the obligation to repay the loan as specified in this agreement, then in this case the Debtor or Guarantor is obliged at his own expense to deliver the collateral to PT. Adira Dunamika Multi Finance Tbk. Pekalongan Branch Office JI.KH.M. Mansyur No. 108 Bendan Pekalongan, Central Java. And is given an 
irrevocable power to take (in bezel nemen) the goods from the Debtor or guarantor or other person who controls them, if necessary with the help of the Police or other relevant authorities.

The problem becomes interesting when the debtor states that the Joint Financing Agreement must be considered null and void along with the inclusion of a standard clause which is considered to violate the provisions of Article 18 paragraph (3) of Law Number 8 of 1999 concerning Consumer Protection, that "Every standard clause that has been determined by the perpetrator businesses on documents or agreements that meet the provisions referred to in paragraph (1) and paragraph (2) are declared null and void. So that the cancellation is retroactive until the moment the agreement is born. What has already been received by one party must be returned to the other party.

While on the other hand, the Creditor felt there was a default because they did not make payments as they should, so confiscation of the collateral was in accordance with the agreement in the agreement. The presumption of bad faith from the debtor by questioning the existence of the contract cancellation shortly after the relevant concerned experiencing payment bottlenecks. The verdict of the District Court judges who won the Defendant because they did not fulfill the 'against the law' element over the existence of a standard clause.

With the fulfillment of these conditions, a fiduciary withdrawal may only be carried out as collateral for the debt that has been used by the fiduciary giver. According to Article 29 of Law Number 42 of 1999 concerning Fiduciary Guarantees, it is stated that the execution of fiduciary objects is carried out by selling conducted by the power of the fiduciary recipient through a public auction, the proceeds of the sale are used to repay fiduciary debt and can be done through under-hand sales based on the agreement of the giver and fiduciary recipients if high prices can be obtained to benefit the parties. The Plaintiff in the a quo case has no right to file a lawsuit against the Defendant because the Plaintiff has proven to have defaulted by not fulfilling his obligations to the Defendant, so the Exceptio Non Adimplenti Contractus principle applies, that "a person has no right to sue; if he himself does not fulfill his obligations under the agreement. "

\section{E. Analysis of court decision number 02 / pdt.g / bpsk / 2014 / pn.bky.}

Position of the case [10], the parties to the dispute are the Fiduciary Giver (Sapari) as the Respondent and the Fiduciary Recipient (PT. Oto Multiartha cq PT. Oto Multiartha Pontianak Branch) as the Petitioner. The dispute originates from the auction of fiduciary security objects by the Petitioner without any summons to the Respondent with the argument that the Respondent has defaulted because it did not fulfill obligations as specified in the Consumer Financing Agreement agreed by the parties. So that the Respondent feels aggrieved and filed a lawsuit to Singkawan City BPSK for the actions taken by the Petitioner.

The standard clause contained in the consumer financing agreement made by the Petitioner 'granting power of attorney from consumers to business actors either directly or indirectly to carry out all unilateral actions relating to goods purchased by consumers in installments'. The clause on the transfer of rights, which states that 'the Debtor agrees and how necessary to hereby authorize the creditor and hence without the need for an official notification or in any form and / or any other way, to mortgage or in any way move and submit receivables or claims - creditor bills based on this agreement with other parties with whom the creditor will make a cessie subrogation agreement, joint financing or other cooperation agreement, along with all rights and guarantees existing by the creditor based on this agreement or deed of guarantee, with the terms and conditions provisions which are considered good by creditors'.

The cancellation of a contract related to the content of the 'standard clause' is part of the consideration of Bengkayang District Court Judges who implement the provisions of Article 18 of the Consumer Protection Act and Article 32 in conjunction with Article 33 of the Law on Fiduciary Guarantees, thereby strengthening the Decision of the Consumer Dispute Settlement Body (BPSK) Singkawang City, that there is a standard clause in the Consumer Financing Agreement Number 10-611-09-01181 (Exhibit P-1) 'null and void'. The meaning of 'null and void' implies that the existence of a clause is considered to be non-existent, but does not invalidate the agreement agreed upon by the parties.

The two Court Desicions above in line with the decision of the Constitutional Court No. 18 / PUU-XVII / 2019 related to the execution of fiduciary guarantees [11], so it clearly provides guidance that the existence of standard clauses that affect the execution of fiduciary guarantees cannot be carried out if made without agreement between the parties.

\section{CONCLUSION}

1. The validity of a contract or agreement is not dependent on the existence of a standard clause, but on the legal conditions of the contract / agreement itself based on Article $1320 \mathrm{BW}$ and the inclusion of the standard clause stated in a contract / agreement of consumer financing becomes null and void if the requirements are met as stated in Article 18 (1) and (2) Law Number 8 of 1999 concerning Consumer Protection.

2. The element of good faith between the parties becomes a counterweight in the event of a dispute between the two parties involved in the consumer financing agreement.

\section{REFERENCES}

[1] Abdulkadir Muhammad dan Rilda Murniati, Segi Hukum Lembaga Keuangan dan Pembiayaan,. Bandung: Citra Aditya Bakti, 2000.

[2] Peter Mahmud Marzuki, Legal Research. Jakarta: Kencana Prenada Media Group, 2010.

[3] Wirjono Prodjodikoro, Principles of Agreement Law. Bandung: Mandar Maju, 2011.

[4] et. al. Firzalia Heirdysbrang, "Consumer Protection of the Standardised Clause ECommerce Agreement 
on the Retail Shopping Site."

[5] A. Muhammad, Hukum Perikatan. Bandung: Citra Aditya Bakti.

[6] Article 18 Law Number. 8 of 1999 concerning Consumer Protection. .

[7] Article 1 (2) Law Number 42 of 1999 concerning Fiduciary Guarantee. .

[8] Achmad Busro and Dewi Sulistianingsih, "Legal Protection For Creditors In Fidusia Agreements In Indonesia," 2017.

[9] Court Decision Number 42 / Pdt.G / 2011 / PN.PKL. .

[10] Court Decision Number 02 / PDT.G / BPSK / 2014 / PN.BKY. .

[11] Court Decision of the Constitutional Court No. $18 /$ PUU-XVII / 2019 related to the Execution of Fiduciary Guarantees. . 